\title{
Beyond Centre and Margin : (Self-)translation and the Eco-poetics of Space in Geetanjali Shree's Mai
}

Martine Hennard Dutheil de la Rochère and Anas Sareen

\section{(2) OpenEdition}

\section{Electronic version}

URL: https://journals.openedition.org/edl/799

DOI: $10.4000 /$ edl.799

ISSN: 2296-5084

\section{Publisher}

Université de Lausanne

\section{Printed version}

Date of publication: 15 September 2014

Number of pages: $379-400$

ISBN: 978-2-940331-35-2

ISSN: 0014-2026

\section{Electronic reference}

Martine Hennard Dutheil de la Rochère and Anas Sareen, "Beyond Centre and Margin :

(Self-)translation and the Eco-poetics of Space in Geetanjali Shree's Mai", Études de lettres [Online], 2-3 I 2014, Online since 15 septembre 2017, connection on 28 juin 2022. URL: http:// journals.openedition.org/edl/799; DOI: https://doi.org/10.4000/edl.799 


\section{BEYOND CENTRE AND MARGIN : (SELF-)TRANSLATION AND THE ECO-POETICS OF SPACE IN GEETANJALI SHREE'S MAI}

This article analyses the use of vegetal and organic tropes in Geetanjali Shree's novel Mai in light of postcolonial translation studies and queer theory as an alternative to the fixed binaries and boundaries of East and West, self and other, that structure "orientalist" and patriarchal discourses alike. Written in the first person, the novel tentatively maps out a new space of enunciation as it relates the development and emancipation of a young woman through the complex relationship that binds her to her mother in a NorthIndian middle-class family. However, this family circle or centre is an ever-evolving one as the postcolonial context in which these female identities are constructed provides new conceptualisations of agency as operating not only through speech but also through strategic silence. Flowering in-between English and Hindi these hybrid agencies force us to revise our critical maps so as to investigate and invest liminal locations in which subjectivities bend the lines of patriarchal structures and static geographies of power.

A space exists when one takes into consideration vectors of direction, velocities, and time variables. Thus space is composed of intersections of mobile elements... Space occurs as the effect produced by the operations that orient it, situate it, temporalize it, and make it function in a polyvalent unity of conflictual programs or contractual proximities... In short, space is a practiced place.

Michel de Certeau, The Practice of Everyday Life, 1984 , p. 117.

(We should) recognise translation as an art to be celebrated, not concealed.

Susan Bassnett, The Translator as Writer, 2006, p. 2. 
It was the English translation of Mai (Hindi, 1997; English, 2000) that put the novel and its author, Geetanjali Shree, on the map of world literature. This is not so surprising as it may seem, since the novel investigates the condition of the postcolonial individual through a poetics of dis-location and (self-)translation in the age of globalisation ${ }^{1}$. A novel that "transcends linguistic and geographical boundaries" ${ }^{2}$, Mai traces a young Indian woman's development from childhood to adulthood as she is pulled between traditional female roles and the mobile, mutable selves made possible by modern life-styles and global exchanges. While it confronts the challenges, anxieties and dilemmas of generational transition, transmission and emancipation through Sunaina's relationship with her mother, the novel also challenges clear-cut divisions and binary oppositions in favor of new, hybrid and fluid forms of being that question the static mapping of centre and margin, self and other, past and present, East and West, that has long structured Orientalist and patriarchal discourses $^{3}$. Our article examines how the novel proposes a new (eco)poetics of identity that represents the self as a mutable, hybrid entity crossing boundaries and blossoming in liminal locations, thus overcoming some of the contradictions of modernity - if only provisionally and tentatively. As such, the novel reflects the narrator's uncertainties about memory,

I. Geetanjali Shree was born in Mainpuri, Uttar Pradesh, in 1957. She chose to be called by her mother's family name. She has written four novels in Hindi: Māà (1993), Hamārā śahar us bars (1998), Tirohit (2001) et Khälī jagah (2006). She has also published several collections of short stories and worked for the theatre. She began her career as a historian, complete with a doctorate and a biography of Premchand, the "father" of modern literature in Hindi, titled Between Two Worlds: An Intellectual Biography of Premchand (1989). The English translation of Mai contributed to her fame as a global author, and the novel has been translated into French and German (among other languages). Shree has received several literary awards and distinctions. She lives mainly in New Delhi, but has also been invited to spend time as a writer in residence in Europe (including Switzerland), as well as in Korea and Japan. Shree brings to contemporary Hindi literature an original touch through her unique/personal use of a mixed Hindi/Urdu lexicon and syntax, her allusive, complex and yet fluid writing style, and her exploration of the subtle interplay of what is said and what is left unsaid.

2. <http://www.zubaanbooks.com/zubaan_books_details.asp? BookID=14>, accessed 23.05.2014.

3. See E. W. Said's classic study Orientalism. 
identity and agency and hence cautions the reader against final truths and definitive interpretations ${ }^{4}$.

The novel depicts how Sunaina grows up in a North Indian middleclass family under the tender care of her gardener-like mother, whose nurturing is described through vegetal imagery. The daughter belatedly recognizes her mother's role in creating a fertile space of freedom in which she could cultivate herself despite the stifling patriarchal environment into which she was born. Sunaina also reevaluates her mother's silence as a subtle effort to protect her daughter against the stringencies of the social order and family control governing her own life. Thus, the text exposes the rigid system that frames women within domestic confines but in doing so, advocates for borderline sites where female agency and creativity manifest themselves. Outlining these liminal locations where new forms of being and linguistic identities come to be cultivated is the primary purpose of this article.

\section{De-centering Orientalism:}

\section{Homi Bhabha's concepts of hybridity and cultural translation}

In Mai, the old metaphor of centre-and-margin gives way to a dynamics of hybridity and in-betweenness better able to represent modern-day lives under "post-postcolonialism" 5 . In Said's definition, Orientalism refers to the production of images of otherness whose main purpose was to bolster the colonizing nation's sense of identity and cultural superiority, and to maintain Europe's political, economic and symbolic dominance over the rest of world. Needless to say, the metaphorical mapping of the world in terms of centre and margin is inadequate in the global age, and Shree's novel invites us to reconsider identity from the perspective of translation instead.

Historically, cartography - like translation - is inseparable from the development of travel, exploration and exchange, and both played an

4. We share Maya Burger's commitment to overcoming binary modes of thinking, and thank her and Rachel Falconer for their careful reading of this article and helpful suggestions.

5. For a definition of the term see, for example, E. O'Connor's "Preface For a PostPostcolonial Criticism". 
important part in the colonial venture. Ashcroft et alii point out that "the world only acquired spatial meaning after different regions had been inscribed by Europeans, and this inscription, apart from locating Europe at the top of the globe or map, established an ideological figuration which firmly centralized Europe as the source and arbiter of spatial and cultural meaning" ${ }^{6}$. Europe was established as the vantage point from which the rest of the world was viewed (mastered, controlled, ruled over), the superiority of the metropolitan centre over the colonial peripheries being established through a complex nexus of power and knowledge. In literary studies, Euro-centrism (or any centrism for that matter) is often masked by notions of authoritative interpretation and methodology claiming universal applicability and relevance. Because postcolonial studies have made us aware of the way power and knowledge operate in discourse, and how forms of neo-colonial influence still shape the world today (and the academic world is obviously no exception), a more politically sensitive and ethically responsible form of scholarship requires a recognition of the intertwining of the intellectual traditions of "East" and "West", and the development of theoretical and conceptual tools that bear witness to their interwoven, complex legacy. In 1975 already, Edward Said pictured the modern literary critic in Beginnings as a "wanderer, going from place to place for his material, but remaining essentially between homes" (p. 8). James Clifford, who has taken up and pursued Said's advocating of "Travelling Theory", notes that the Greek term theorein itself implies "a practice of travel and observation", "a product of displacement, comparison, a certain distance":

To theorize, one leaves home. But like any act of travel, theory begins and ends somewhere. In the case of the Greek theorist the beginning and ending were one, the home polis. This is not so simply true of traveling theorists in the late twentieth century.

"In light of such decenterings", Clifford adds, to theorize "becomes a newly problematic activity" 7 . Because we should be distrustful of any theory, model or method that proclaims its own centrality, we propose

6. B. Ashcroft et al., Key Concepts in Post-Colonial Studies, "Euro-Centrism", p. 91.

7. J. Clifford, "Notes on Travel and Theory". See also Bruce Robbins's plea for a "new cosmopolitanism", though he is aware of the privileges of the cosmopolitan intellectual. 
a move from the spatial metaphors of centre and margin (an "assumed topography" to use Clifford's words) to a more dynamic understanding of contemporary literary productions inspired by cultural translation, which Homi Bhabha defines as a "poetics of relocation and reinscription" in The Location of Culture 8 that "desacralizes the transparent assumptions of cultural supremacy" ${ }^{9}$. Because it also challenges established disciplinary boundaries, we further propose to displace "theory" and "translation" (which themselves derive from the idea of movement) by combining translation theory, queer theory and eco-criticism in our analysis of the representation of postcolonial agency and identity in the novel ${ }^{10}$. This theoretical crisscross seeks to address the mixing of spatial and organic metaphors in Geetanjali Shree's Mai to convey the making of a hybrid, mobile and transgressive postcolonial agent.

\section{Cultivating In-Betweenness}

Cultural translation designates the process of transformation, linguistic and otherwise, that takes place when we move from one cultural environment to another. Susan Bassnett has stressed the productive links between translation studies and postcolonial theory, and noted that the globalization of translation as involving intercultural communication and exchanges well beyond Europe and the West raises issues of power, cultural domination and influence. Because the processes of globalization notably destabilize fixed notions of (gendered) identity, traditional structures and dominant values, as well as naturalized national, linguistic and cultural boundaries, translation takes on many forms and transgressive varieties.

8. H. K. Bhabha, The Location of Culture, p. 225.

9. Ibid., p. 228.

Io. Susan Bassnett has identified a profound transformation in comparative literature under the twin pressures of postcolonial theory and translation studies since the 1980s. Quoting from The Empire Writes Back, she calls for a "post-European model of comparative literature" reflecting a "hybridized [...] view of the modern world": "one that reconsiders key questions of cultural identity, literary canons, the political implications of cultural influence, periodization and literary history" (S. Bassnett, Comparative Literature, p. 41). 
The work of cross-cultural and multilingual writers like Geetanjali Shree lends itself particularly well to the model of cultural translation theorized by Bhabha, inasmuch as it thematizes and enacts a precarious, but strategic, position in-between languages, cultures, values and worldviews. Significantly, Bhabha wrote The Location of Culture partly in response to Salman Rushdie's The Satanic Verses, thereby illustrating the productive interplay of fiction and theory. For Bhabha, cultural difference is perceived, articulated and performed in and through translation:

We should remember that it is the "inter" - the cutting edge of translation and renegotiation, the in-between space - that carries the burden of the meaning of culture ${ }^{11}$.

The Satanic Verses, which begins with a bang in air-space, presents an inaugural scene of (self-)translation that puts meaning and identity into motion by literalizing metaphors:

"O, my shoes are Japanese," Gibreel sang, translating the old song into English in semi-conscious deference to the uprushing host-nation, "These trousers English, if you please. On my head, red Russian hat; my heart's Indian for all that." [...] Up there in air-space, in that soft, imperceptible field which had been made possible by the century and which, thereafter, made the century possible, becoming one of its defining locations, the place of movement and of war, the planet-shrinker and power-vacuum, most insecure and transitory of zones, illusory, discontinuous, metamorphic [...] anything becomes possible ${ }^{12}$.

Prior to writing The Satanic Verses, Rushdie had already proposed to see the migrant as an emblematic figure of the postcolonial condition: "The word 'translation'", he notes, "comes, etymologically, from the Latin for 'bearing across'. Having been borne across the world, we are translated men. It is normally supposed that something always gets lost in

II. H. K. Bhabha, The Location of Culture, p. 26.

I2. S. Rushdie, The Satanic Verses, p. 5. The song is "Mera joota hai japaani" from the 1955 film Shree 420 (Mr. 420), directed by Raj Kapoor, music by Shankar Jaikishen, lyrics by Shailendra and Hasrat Jaipuri. For a detailed analysis of the opening of the novel, see M. Hennard Dutheil de la Rochère's Origin and Originality in Salman Rushdie's Fiction. 
translation; I cling, obstinately to the notion that something can also be gained" 13 .

Like Rushdie, Geetanjali Shree reconceptualises space, time, identity, memory and writing from an in-between, cross-cultural perspective that unsettles the binary logic of East and West, self and other, Hindi and English. Although her work explores various modalities of translation, however, Shree's writing couldn't be more different from Rushdie's: her intimate, thoughtful, self-conscious, lyrical prose radically contrasts with his loud, exuberant, extravagant, provocative signature style. While Rushdie's fiction is notoriously male-centred, Shree's Mai focuses on female trajectories. Moreover, Shree has strongly reacted to Rushdie's polemical proclamation that the best of Indian literature today is written in English, and she chooses to write fiction in Hindi, albeit in a way that foregrounds its multi-layered and hybrid nature.

In Mai, Geetanjali Shree undermines the fixity of binary oppositions to explore the dynamic, shifting and mutually defining (inter-) relationships between Hindi and English, past and present, mother and daughter, self and other, language and silence, to the point that it becomes almost impossible to disentangle them. Mai arguably thematizes and enacts the spatial metaphor of in-betweenness in the plot as much as in the writing itself. The novel was originally written in Hindi and subsequently translated into English by Nita Kumar, an Indianborn cosmopolitan academic based in the US : only then did it reach a broader audience both in India and abroad, and achieve international recognition. The novel takes on new resonances in English, including the relationship between mother and daughter in which language plays a significant part (more about this below). Geetanjali Shree made a point of writing the novel in her mother tongue for personal, aesthetic

I3. S. Rushdie, Imaginary Homelands, p. 13. "For Bhabha, the recognition of the ambivalent space of cultural identity may help us to overcome the exoticism of cultural diversity in favour of the recognition of an empowering of hybridity within which cultural difference may operate. [...] While assertions of national culture and pre-colonial traditions have played an important role in creating anti-colonial discourse and in arguing for an active decolonizing project, theories of the hybrid nature of post-colonial culture assert a different model for resistance, locating this in the subversive counterdiscursive practices implicit in the colonial ambivalence itself and so undermining the very basis on which imperialist and colonialist discourse raises its claim of superiority." (B. Ashcroft et al., Key Concepts in Post-Colonial Studies, p. 118-121). 
and political reasons spelled out in her essay "Writing Is Translating Is Writing Is Translating Is...", which posits translation as a key to literary creation ${ }^{14}$. Furthermore, Nita Kumar herself was troubled by the idea of translating the novel in the former language of empire, as she explains in the afterword to the English edition. She admits that she is "uncomfortable with the role I seem to be performing - that of the critic certain of the 'nature' of literature and of the way to read it, convinced of the mimetic view of literature [...]. This humanist, empiricist, and idealist view that takes language to be transparent and experience to be prior, is exactly what I would like to eschew" ${ }^{15}$. Kumar cautions against the fixity of authoritative interpretations and prefers to see her translation as a subjective, performative and provisional reading of the text as a feminist novel that problematizes the construction of "woman". To address the unease of mediating the text to Anglophone readers, she deliberately uses English as an Indian language interspersed with words and phrases in Hindi and Bengali to inscribe linguistic and cultural difference from the prescribed norm. Kumar does not evade the contradictions and paradoxes of her own position as a privileged cosmopolitan intellectual, either. She notes that Hindi is her mother tongue, but that she has a greater mastery of English: "The 'problem' of the mother", she says about Mai, "is also the problem of the 'mother' tongue. And equally insoluble. But equally, I hope, worthy of being pursued" ${ }^{16}$, she concludes in open-ended fashion ${ }^{17}$.

The analogy that the translator establishes between the silent - and silenced - mother in Mai and the displaced Hindi text (from Māi to the Anglicized Mai) is quite suggestive: the author and the translator

I4. The paper was given at the Translating India conference (University of Lausanne, Nov. 6-8 2008, organised by Maya Burger and Nicola Pozza), and published in India in Translation (2010). It also appeared in the bilingual literary journal Pratipili (<http:// pratilipi.in/2008/12/hello-how-are-you-i-hope-geetanjali-shree/>, accessed 23.05.2014).

I5. N. Kumar, “On Translation”, p. 197.

I6. Ibid., p. 204.

17. Translation is, indeed, neither neutral nor transparent: it is bound up in power relations, whether economic, commercial, political, or cultural. Nita Kumar tries to preserve the puns, rhythmic repetitions, sound patterns, syntactic turns, and shifts in tone, register or diction that challenge the hegemonic position of English as a "master language" worldwide, and " $\operatorname{draw}(\mathrm{s})$ attention to the materiality of language, to words as words, their opacity, their resistance to empathic response and interpretative mastery" (L. Venuti, Rethinking Translation, p. 4 and 12). 
both evoke the loss of an origin - the mother, the mother tongue, or the mother-text - with an ambivalence tinged with nostalgia. But they also recognize that it is their absence that made the novel possible, let alone its translation. The complex interrelationship between mother and daughter, author and translator, Hindi and English, therefore remains an open question, and one which resists a finalized solution.

Moreover, opposing Hindi and English would be reductive and simplistic, since Hindi was standardized within the context of colonial India, in close relation to and in opposition with English. Hindi also borrows from English vocabulary besides Sanskrit, Urdu, and other Indian languages, and Geetanjali Shree makes sure to reflect this inherent hybridity in her writing style. Conversely, English is multi-layered, and as a formerly colonial and now global language is shot through with borrowings from the many languages of India. In her translation, Nita Kumar also emphasizes the constitutive hybridity of the English language, especially as it is used in the Indian context. Geetanjali Shree herself questions the opposition of English and Hindi in "Writing Is Translating Is Writing Is Translating Is...” when she states:

Take writers like me. Bilingual from childhood in a formerly colonized and now formally decolonized part of the world. It is no ordinary bilingualism. It is not about to-ing and fro-ing from one language to another $[\ldots]$ it is about to-ing and fro-ing between one mixed, hotchpotch, khichdi language to another mixed, hotchpotch, khichdi language! English-Hindi-dialects mix to dialects-Hindi-English mix! [...] Our attempts to resolve this confusion or babble is what makes for the enrichment and renewals of our worlds ${ }^{18}$.

Translation, then, is no mere shuttling between East and West, home and the world, mother and daughter, tradition and modernity, past and present. It is the recognition that there was hybridity (or mixing) from the very beginning: and this is the rich soil from which both the novel and its translation emerged.

The image of translation as an organic process has a long history, but as Susan Bassnett suggests in "Transplanting the Seed" 19, it can be reactivated today to think about translation as cross-cultural transfer

I8. G. Shree, "Writing Is Translating Is Writing Is Translating Is... ”, p. 268.

I9. S. Bassnett, "Transplanting the Seed". 
and vital practice of re-creation across borders. Likewise, the representation of hybrid identities in Mai's "post-postcolonial" context sheds light on the socio-historic sites or soils in which cross-bred figures may spread their roots and blossom, or wither and dry out. The performativity of translation as transplantation is therefore linked to the subject's active enactment of hybridity for self-preservation and self-creation. Shree discusses the dynamic interplay of writing and/as translating, which occurs in a creative "in-between" site of fruitful collision:

As a writer I know one thing: the most exciting, both for its pain and ecstasy, is the site where two expressions meet or collide. It is there that inspiration sparks, and from it creativity arises. This is the site where the inarticulate meet the articulate, where one language meets another, where translation of all kinds occurs. A fluid site $[\ldots]^{20}$.

Shree insists on the creative potential of liminal sites where languages meet and mix. Their encounter takes place in a borderline space "where translation of all kinds occurs": the self is translated in the act of writing, just like the text itself lives on when it is translated into another language and cultural context. For Shree, then, writing itself entails self-translation. As she puts it: "Expressing any impression in words is itself a translation - the inarticulate is translated into the articulate". Translation, then, postulates a certain ethos of writing: open to the m/other within the self (the other voice, language, culture), not fixed or static but dynamic, fluid, performative and sensitive to difference. As a result, self-identity is neither possible, nor even desirable. This, incidentally, may explain why the author gave up the idea of translating her own fiction into English, as if somebody else's voice, in dialogue with her own, was a prerequisite for translation to be re-created in another context.

Such attention to borderline spaces of creativity most definitely results from the "hybridity at heart" within Shree herself: "From the cultural, emotional, uprooting, a new process of individual and collective being has sprung. My moment encapsulates hybridity" ${ }^{21}$. More than an individual and therefore self-contained agency, what Shree underlines is the collectiveness behind her own writing. An awareness of the social and

20. G. Shree, “Writing Is Translating Is Writing Is Translating Is...”, p. 267.

2I. Ibid., p. 269. 
political discourse in her work brought to light by a process of transplantation, or as she puts it "uprooting", thus generating consciousness of the "post-postcolonial" environment in which she and her characters evolve. Even more than hybrid space, Shree insists on the hybrid time in which she lives: "my moment encapsulates hybridity". Her "mixed up speech" carries these seeds of hybridity in and through the novel, as vital aspects of the representation of a new generation (and perhaps even a new species) of beings. But this hybridity should also characterize the novel in translation, whereby the literary text is viewed as a living ecosystem that one must try and preserve while transplanting it into another language: to translate, according to Shree, is "an on-going process of creativity", just like writing itself. She adds: "I am [...] simply stressing the need for translation to encompass the atmospheric space and not just begin and end with the bare, obvious, text" (p. 274). The atmospheric climate surrounding the text is therefore of utmost importance to her because it is vital for the translator to maintain the fertile process of creativity as opposed to a sterile rendition of "the bare, obvious, text". Moreover, Shree evokes the idea of "pulse" that animates a text. But this vital signal may also be at play in the concept of transgression itself:

It is [...] not merely the breaking of a code, a rebellion against normative social or cultural constraints; rather, it is the very pulse that constitutes our identities $[\ldots]^{22}$.

If the lines of the text might seem set, the transgressive act of translation as creative re-invention or transplantation enables the text to "pulsate richly" so long as its ecosystem is itself transported by the reader's own organic reading.

As Shree observes in the same essay, Mai is steeped in the manifold effects of linguistic, literary and cultural displacement. The novel is narrated from the point of view of Sunaina, a young woman who returns to the family house in Northern India after living abroad: she looks back upon her childhood and honours the memory of her mother, Mai, who slowly, inconspicuously, tenaciously created a space in which her daughter could grow, cultivate herself and come into blossom. The novel presents itself as a fictional memoir where Sunaina's life and emerging sense of self is inseparable and yet distinct from that of her mother: the

22. J. Wolfreys, Transgression, p. 1. 
focus of the narrative constantly shifts from daughter to mother, whose story resists being told since Mai was a selfless and silent presence in the home, or so her children perceived her to be. From the perspective of adulthood, however, the daughter becomes aware of the role that her mother played in her own emancipation, as she carefully uprooted her from the dry, barren, context of patriarchal reproduction of gender stereotypes whereby daughters are raised into patient and uncomplaining wives, hard-working home-makers, long-suffering daughter-in-laws, and devoted mothers. Under Mai's care, Sunaina freed herself from the selfsacrificial fate which her own mother couldn't escape. She recognizes that she misconstrued her mother's silence and submission as passivity, weakness and helplessness, and even understands that her mother had some agency within the family, especially when it came to the nodal problem of her children's access to education. Sunaina further reflects on the predicament of capturing the silent, secretive and elusive figure of the mother in a web of words. The text thus revolves around the necessity, and yet the impossibility to tell the story of the mother in her own voice; it can only be memorialized indirectly and imperfectly by the daughter/narrator. In this sense, Mai is the true agent of cultural translation, the one who brings about social and cultural change. Mai is, simultaneously, the subject and object of cultural translation as it is through her that her daughter comes to understand her own identity and individuality; the relationship between mother and daughter is therefore one intimately based on a process of translation, organically negotiating the constitution of the self through the figure of the other.

If the boundary of the self is repeatedly overcome, translation is also spatially enacted and manifest in the representation of boundary crossing. The narrative pits the family home in which Mai is confined, against what lies outside its walls, i.e. the nearest city of Lucknow. Moreover, beyond Lucknow lies England representing access to higher education via the boarding school where Subodh, Sunaina's brother, is sent to study. Mai's achievement is to ensure that her children can leave the home to study and travel, though their own naive attempts to "get Mai out of the home" (a leitmotif that runs through the novel) will never succeed. Over time, however, the constant efforts of dada, the patriarch and uncontested authority in the home, whose desire is to maintain a clear separation between inside and outside, and to keep the women inside the home, is eroded. Foreign influences are marked not only by 
the children learning English and being schooled outside the home, but even more by the adoption of Western food and commodities. The consumption of English branded products, although it increases Mai and the servant Hardeyi's workload, foregrounds the cultural hybridity that will constitute the children's experience of the "outside" world. Crossing boundaries, moving between inside and outside, is therefore associated with freedom, learning, and the possibility of self-invention, which destabilizes mono-cultured norms.

One obvious instance of cross-cultural translation is situated on the linguistic plane, and it raises the question of the gendered access to the English language, and to knowledge generally:

Dada wanted that I should learn English.

But not speak it. Or Hindi either. That is, not speak at all ${ }^{23}$.

Dada and babu practised their English on him (Subodh) at every chance. Mai did not know English. Dadi could not even speak straight Hindi. The corners of our house echoed with many tongues. [...] Subodh promised me, "I will teach you good English, make sure you have a great accent, get you out of here..." 24 .

It's true that I had reached a point where I would have won a competition for mixed speech. I could not speak a sentence without jumbling up languages. The languages were, one of the "heath", the other of the "melon", English and Hindi. A whole sentence could be in English but at least one word would have to be in Hindi - "I was saying ki..." And if I was speaking in Hindi, the same thing - "Wah before a gayi thi to main tayar...".

Subodh became critical of this eloquent technique. [...] I often repeated myself in English but also often kept silent in stubbornness ${ }^{25}$.

Sunaina's learning English is tolerated, although her idiosyncratic, hybrid speech is resented by her brother. One may also note that Sunaina's relationship to English is based on a performative enactment of language ("I often repeated myself in English") but the girl also performs silence as a means of resistance to the norm imposed by her brother. Noticeably, her mother implicitly transmits this powerful use of

\footnotetext{
23. Ibid., p. 30.

24. Ibid., p. 36

25. Ibid., p. 53
} 
silence and Sunaina constructs her being as a fluctuating entity negotiating between speech and silence. Interestingly, when we read the novel in Hindi, it is in the language of Sunaina's mother and the author's own mother tongue; but when read in English, the novel speaks and itself performs the language of difference, alienation and nostalgia, but these themes are also connected to female empowerment through education and self-assertion, thereby revealing the difference in/of translation.

As mentioned before, the structuring of space submitted to class, gender and generational lines, and the division between "inside" and "outside" drawn by the grandparents, comes to be blurred through the children's playfulness. In Gaga Feminism: Sex, Gender and the End of Normal ${ }^{26}$, queer theorist Judith "Jack" Halberstam sees the child figure as an essentially non-normative being capable of creative collisions that adulthood usually refutes: "Children are different from adults in all kinds of meaningful ways. They inhabit the passing of time differently" ${ }^{27}$. According to Halberstam, the child occupies an enhanced position when it comes to the exploration of space and time. This ubiquitous power also applies to discursive constructions allowing the child to "seamlessly transition between topics". The first chapter of Mai displays the interaction of these elements as the narrative is structured around childhood memories:

We could be hidden somewhere on the roof dreaming up stories. We could be at the well watching the bullocks doing their rounds irrigating the fields. We may not have been that good at climbing trees but we could certainly swing from some of the guava branches [...] There were many ways to escape dada ${ }^{28}$.

The peripheries of the house (roof, fields, trees) represent Edenic locations that are described by the narrator in dynamic fashion enhancing the children's relationship with the natural world and drawing the reader into the textual garden. As the syntactic cuts underline spatial ones, sentences relate the once enacted, and now remembered, joyful exploration of space linked to childhood. However, the invisible boundaries are crossed so as to avoid the narrative's first figure of authority. Described

26. J. Halberstam, Gaga Feminism, p. XXIII.

27. Ibid.

28. G. Shree, Mai, p. 4. 
as entertaining a "relationship with the rest of the house [that is] simply one of intimidation" (p. 4) dada incarnates the patriarchal force under whose pull the characters first rotate. Nevertheless, while dada's authority covers the rest of the household it also reveals the marginal sites in which the children "go gaga". Their ability to wander physically and imaginatively reflects an awareness of limitations, but also and more importantly their creative transgressions. Fiction-making, as displayed by the children hiding on the roof to "dream up stories", operates in a child-like, transgressive manner that "disturbs borders and the understanding of what is included and excluded by any boundary," so that "it can be argued that memory [...] transgresses a border between what is real and what is phantasmatic" ${ }^{29}$. Applied to the literary text, of course, the "real" and the "phantasmatic" become blurred in the fiction-making process. Memory allows the narrator to be part of the diegesis while simultaneously permitting her to comment on the story, and on her younger self, from a distance ${ }^{30}$. Thus, she navigates between the various fictional levels, crossing temporal strata, shifting points of view and narrative positions. Traces of such crossings become prominent in meta-fictional passages that comment on the unfolding of the narrative, and cast doubt on the adequacy of fiction to apprehend such an elusive, mysterious and complex figure as Mai.

In the first chapter of Mai already, the narrator draws on a spatial metaphor to express the difficulties of writing about her mother: "I want to narrate 'Mai' but the distance between 'Mai' and the narration is so troubled, so full of opposition, that one doesn't know how to cross that distance or what might happen on the way" ${ }^{31}$. Sunaina reflects on the immeasurable distance that separates her from her " $m /$ other", and on the reductive, distorting effects of writing; and yet, writing nevertheless becomes the "in-between" space connecting past and present and bridging the gap that separates her from her mother, although she admits that this can never be fully, or satisfactorily, achieved:

29. J. Wolfreys, Transgression, p. 10.

30. On the transgression of fictional levels by the narrator, see G. Genette's Métalepse.

3I. G. Shree, Mai, p. 3. 
Memory, which is the past caught in an imaginary frame, not so much untrue as incomplete. The fear is not only that the story will be halftold, but also that the story remains true only until it is captured in a frame. As soon as "it" is held, "it" will take on a new shape, become solid, a frozen part of history. Do we really want to gather all the things we find possible to say in this way, and deny the truth of the unsaid? ${ }^{32}$

Framing the story inevitably creates arbitrary boundaries, selects episodes and traps the characters into prescribed roles. The danger of the "frame" resides in the idea of freezing the subject or object. The narrator also highlights the ambiguous status of the "unsaid" which itself constitutes an undeniable part of the "truth". Silence therefore comes to define not only the mother but also the paradox out of which the daughter's narrative grows.

While Sunaina's access to the past is problematized in meta-fictional asides and structural discontinuities, space plays an important role in the diegesis as it reflects the hierarchical relations between characters and delimits gender, class and age divides. Even so, the novel presents communication taking place "at the boundaries", where "objects, messages and scoldings (are) exchanged" 33 . The nature of such borderline exchanges fall into two main categories: "messages" and "scoldings", denoting the repressive atmosphere in the home. The separate spaces of the household are delimited and policed through the repetition of orders, commands, requests or complaints. In reaction to the imperatives framing domestic life, Sunaina displaces and bends the household limits extending them to those of the surrounding garden. Nevertheless, as she grows up, the need to break away from the paradisiac garden of her childhood becomes manifest for she realizes that it constitutes some sort of enclosed garden ${ }^{34}$. Her first childhood endeavor then is to bring other characters into her game of spatial exploration as she attempts to acquire new artistic abilities:

32. Ibid., p. 2.

33. Ibid., p. 5.

34. One of the etymologies of paradise is "A garden esp. an enclosed one; an orchard; an enclosed area or court in front of a building". OED, paradise. n. (II, 4, a). 
I got after Mai and she spoke to Nagji Appa's sister in the club and arranged for her daughter's teacher, Ustad Nanhe Khan, to come to our house to teach me dance. He would have to climb over the barbed wire at the back and come in through the courtyard. After everything had been arranged, Nahne Kahn messed it all up. He did not understand the subtlety of the arrangements. After leaving the courtyard he decided that it would be easier to exit by the front gate and take a rickshaw in the bazaar. Dada caught him, gave him a talking to, discharged him... ${ }^{35}$

The pronominal change from the former "We" to the single "I" marks a transition from the undifferentiated gender of brother and sister during early childhood to the experience of separation, self-constitution, growing assertion and autonomy ${ }^{36}$. Sunaina's creative energy enables her to build (or rather enact) her own "self" : interested in learning how to dance, she involves other female figures (her mother, Nagji Appa's sister) and even a male teacher. She brings Nagji Appa to cross the physical boundary that separates the garden from the outside, and hence undermining patriarchal control and social norms. The garden represents the ideal space in which to observe and to experiment with limits. It therefore provides the terrain in which Sunaina's creative power is let loose, unsettling fixed binaries and boundaries. Subsequently, the male-female divide is disturbed when the transmission of knowledge no longer falls into gendered divisions.

Although Sunaina is successful in initiating the transgressive act, the male subject fails to durably perform it. His failure is linked to a misreading of the social and family context in which he is called. When he decides "that it would be easier to exit by the front gate" the dance teacher fails to understand the power structure the household space is regulated by and the "easy option" proves to be the wrong one.

35. G. Shree, Mai, p. 29 sq.

36. Further on in the narrative, Sunaina explicitly brings up this question: "We had grown up and could not stay together any longer. We could come together on the same side but we also realized that we had our separate truths. We realized that the soundlessness that surrounded the vast terrain of pleasure and pain, bondage and freedom of everyday life may be the same in principle but was a different experience for each person. It had a certain colour for me, for us women [...]" (Ibid., p. 127). The character here underlines the presence of a "common gendered ground" but also observes a gender divide, which is not present in the early childhood experience. 
Sunaina's transgression can only be an isolated, ephemeral act, unlike the subtler and durable effects of motherly care still active even in spite of dada's repressive rule and dadi's chidings.

Later on, during her adolescence, Sunaina constitutes herself in opposition to her mother, though the struggle between identification and rejection continues well after the latter's death:

Mai, who was always giving, was a part of me. [...] I cannot become another Mai. Mai herself is a vanishing species. Even if I could become another Mai I would not like to be one. I will not be one. I will fight to the death not to be another Mai. I want to pull out of myself every bit of Mai ${ }^{37}$.

When Sunaina recognizes the part of her mother in herself, her first reaction is an almost instinctual rejection for self-preservation: seeing her mother as "a vanishing species", the daughter understands that it is of vital importance to exclude her mother from herself if she wants to become an autonomous individual and acquire a voice of her own. Sunaina therefore defines her own limit concerning speech and silence, and realizes that education will be not only her "way out" but also participate in her self-definition:

Something had happened to me, only to me, after that first burst of excitement when I had left the house for the open outside. The longing to learn everything became moulded into a balance. I became more and more myself [...] Fired with the desire to learn, I kept becoming free of values, of bonds ${ }^{38}$.

Here again, Sunaina's exhilarating exploration of space is closely linked to the issue of learning. This time, however, the instantaneous joy of the "outside" experience does not wither to nothingness; whereas it is repeatedly evoked that Mai's "fire is turned inwards" ${ }^{39}$, her daughter's flame propels itself beyond the household limits. Sunaina's desire for knowledge turns education into an instrument of emancipation that sets her "free of values" and "bonds", barriers and imposed boundaries.

37. Ibid., p. 56 sq.

38. Ibid., p. 101.

39. Ibid., p. 41. 
As noted above, Sunaina's self-invention cannot be dissociated from her ability to create hybrid linguistic constructs. Accordingly, her hybridity is constituted (and constitutes her) through a performative process by which discursive norms are challenged, taking the forms of creative "mixed speech" 40 . The vegetal lexicon she uses symbolizes the cultural interferences that participate in the construction of her multicultural being. The "heath" and the "melon" also hint at the natural conditions of language acquisition and puts it to play in a playful, creative way. Therefore, in light of the postcolonial context in which the narrative takes place, Sunaina represents a new generation of hybrid individuals germinating from the productive encounter between the two cultures. As she puts it at the beginning of the novel: "Maybe we are cross-breeds, spotted, some wild exotic plant. But that's us" (p. 9). The hybridity of the subject is here again expressed through an organic metaphor that re-inscribes "exoticism" away from colonial rhetoric into joyful, celebratory self-assertion of "post-postcolonial” identity.

If Sunaina eludes linguistic distinctions between Hindi and English during her childhood, her adolescent years are marked by an acute awareness of the socio-political status of each language. Conscious of a pronounced (and pronounceable) difference, Sunaina and her brother affirm their generational difference through discursive upsurges:

Once babu, in a completely innocent voice, called Mai ignorant. Our childhood memories were awakened. Then too she had been called "ignorant" in the club on one occasion. Today could we quietly accept this talk of knowledge and ignorance? We were provoked. "It's you who, outwardly educated, are ignorant and superstitious." And added in English - "You talk like a foolish illiterate." Mai was angry. "Have you been given permission to say nonsense you like in English?" 41

40. "Code-switching is the use of material from two (or more) languages by a single speaker in the same conversation [...] The general topic is sometimes subdivided into two categories, code switching - intersentential switching, which is switching from language to another at the sentence boundary - and code mixing [...] within a single sentence" (S. G. Thomason, Language Contact, p. 132). What the concept of "code mixing" points out is the dynamic structure of languages and the creative space that is formed when two languages are used simultaneously.

4I. G. Shree, Mai, p. 93. 
In an awkward attempt to defend Mai, the children unite to counter their father's dismissive comment about his wife's alleged "ignorance". Recalling a time in which they could only be passive observers, Sunaina and her brother are conscious of a significant change that allows them to "talk back". It is no coincidence that the topic that provokes their angry outburst should be related to the question of knowledge, education, and access to English. The children's hostility is also conveyed by the fact that they retort in English, which interpellates the reader too. The children's use of the English language in an open confrontation with their father recalls the colonial experience that posited English as the language of authority. Ironically, their confrontation with oppressive masculine authority on behalf of the mother merely displaces the repressive agency of the father, since the mother speaks only Hindi. Their outburst mimics a sterile colonial attitude that first excludes her, but subsequently provokes her verbal reaction: Mai's frustration finally allows her to cross a (self-)imposed barrier of silence. Sensing a counter-productive use of English that she calls "nonsense", she refutes her assigned position as a silent victim, hence contradicting the image that her children have of her. Hereafter, what the narrative itself refutes is an over-simplified reading of characters through the binary division of speech $v$ silence, where speech connotes individuality and agency, and silence powerlessness. Mai will ultimately provide the fertile earth in which her daughter can cultivate herself.

Finally, the cross-breeding of identities on the narrative and textual level calls for a cross-breeding of literary theory itself. We have seen how permeable the boundaries between inside and outside become around sites of productive transgression, and this may be seen as an invitation to read texts at the borderline of disciplines. Translating critical approaches beyond disciplinary boundaries may allow us to unsettle the lines that structure our critical map. If the lines of power are those that draw maps, then representations cannot be dissociated from the colonial apparatuses they participate in creating. Therefore, it would seem naïve to claim that postcolonial criticism and eco-poetics can overcome the power structures that construct such cartographies altogether. Nevertheless, by revising the concepts of centre and margin, we can rewrite our critical maps so as to include spaces of individual cultivation 
like those created by subjectivities that stem out of colonialized soils, and flower into multilingual, hybrid and in-between beings.

\author{
Martine Hennard Dutheil de la Rochère \\ University of Lausanne \\ Anas Sareen \\ University of Lausanne
}

\title{
BIBLIOGRAPHY
}

Ashcroft, Bill, Griffiths, Gareth, Tiffin, Helen, Key Concepts in Post-Colonial Studies, London/New York, Routledge, 1998.

Bassnett, Susan, Comparative Literature: A Critical Introduction, Oxford, Blackwell, 1993.

-, "Transplanting the Seed: Poetry and Translation", in Constructing Cultures: Essays on Literary Translation, ed. by S. Bassnett, A. Lefevere, Clevedon, Multilingual Matters, 1998, p. 57-75.

Bassnett, Susan, Bush, Peter (eds), The Translator as Writer, London/ New York, Continuum, 2006.

Bнавна, Homi K., The Location of Culture, London/New York, Routledge, 1994.

Certeau, Michel de, The Practice of Everyday Life, trans. Steven Rendall, Berkeley, University of California Press, 1984.

Clifford, James, "Notes on Travel and Theory", <http:// culturalstudies.ucsc.edu/PUBS/Inscriptions/vol_5/clifford.html> (accessed 23.05.2014).

Genette, Gérard, Métalepse, Paris, Seuil, 2004.

Halberstam, Judith, Gaga Feminism: Sex, Gender, and the End of Normal, Boston, Beacon Press, 2012.

Hennard Dutheil de la Rochère, Martine, Origin and Originality in Salman Rushdie's Fiction, Bern, Peter Lang, 1999.

Kumar, Nita, "On Translation”, in G. Shree, Mai: a Novel, New Delhi, Kali for Women, 2000, p. 197-204. 
O'Connor, Eric, "Preface For a Post-Postcolonial Criticism”, Victorian Studies, 45 (2003), p. 217-246.

Rushdie, Salman, The Satanic Verses, London, Viking, 1988.

—, Imaginary Homelands: Essays and Criticism 1981-1991, London, Granta Books, 1992.

SAID, Edward W., Beginnings: Intention and Method, New York, Colombia University Press, 1975.

—, Orientalism, London/New York, Penguin, 1978.

Shree, Geetanjali, Between Two Worlds: An Intellectual Biography of Premchand, New Delhi, Manohar, 1989.

—, Mai: a Novel, trans. from Hindi by Nita Kumar, New Delhi, Kali for Women, 2000.

—, "Writing Is Translating Is Writing Is Translating Is...", in India in Translation through Hindi Literature, ed. by M. Burger, N. Pozza, Bern, Peter Lang, 2010, p. 267-276. Also reproduced in Pratipili, a Bilingual Literary Journal (Dec. 2012): <http://pratilipi. in/2008/12/hello-how-are-you-i-hope-geetanjali-shree/> (accessed 14.10.2013).

Thomason, Sarah G., Language Contact: An Introduction, Washington, Georgetown UP, 2001.

Venuti, Laurence, Rethinking Translation: Discourse, Subjectivity, Ideology, London/New York, Routledge, 1992.

Wolfreys, Julian, Transgression: Identity, Space, Time, Hampshire/New York, Palgrave Macmillan, 2008. 